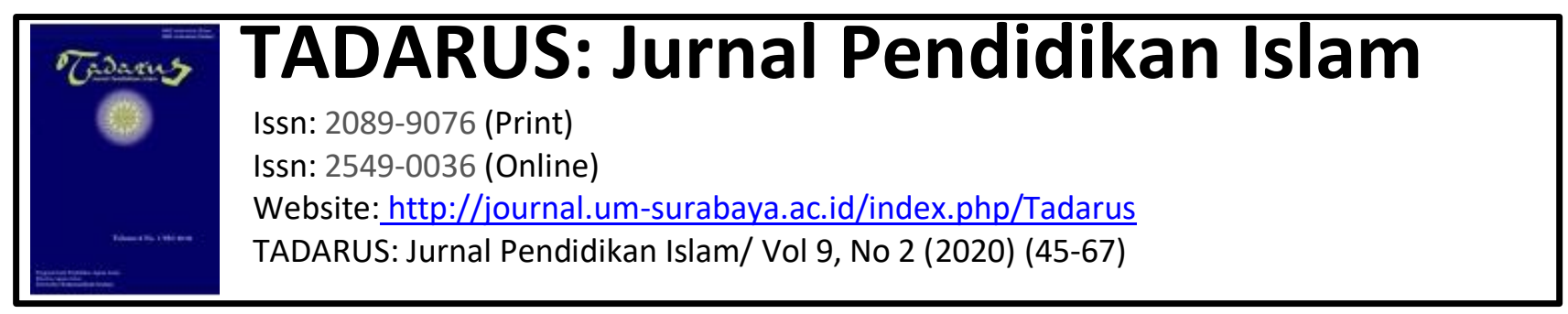

\title{
KUALIFIKASI DAN TANGGUNG JAWAB PENDIDIK DALAM PEMBELAJARAN PENDIDIKAN AGAMA ISLAM PERSPEKTIF AL-QUR'AN-HADITS
}

\author{
${ }^{1}$ M. Ahyan Yusuf Sya'bani, ${ }^{2}$ Su'aib Muhammad, ${ }^{3}$ M. Samsul Ulum \\ ${ }^{1}$ E-mail: 200101310003@ student.uin-malang.ac.id \\ ${ }^{123}$ Universitas Islam Negeri Maulana Malik Ibrahim Malang
}

\begin{abstract}
ABSTRAK
Konteks pendidikan terutama dalam pendidikan Islam, tentunya memandang penting untuk mencapai suatu tujuan pendidikan, seorang pendidik menjadi tokoh utama dalam mengantarkan peserta didik untuk sukses mencapai tujuan pendidikan. Pendidik yang dikenal juga sebagai seorang guru merupakan orang yang bertanggung jawab terhadap setiap perkembangan peserta didik dalam menuntut ilmu. Begitu sentral dan pentingnya posisi seorang guru dalam dunia pendidikan, maka Islam dalam ajarannya juga sangat menghormati dan menjunjung tinggi profesi sebagai seorang pendidik yang banyak dijumpai dalam ayat-ayat al-Qur`an maupun teks-teks Hadits. Berdasarkan alasan tersebut, maka dirumuskan suatu permasalahan untuk melihat lebih dalam bagaimana perspektif al-Qur'an dan Hadits tentang kualifikasi dan tanggung jawab pendidik dalam pembelajaran Pendidikan Agama Islam. Hasil yang didapatkan menunjukkan bahwa dalam al-Qur'an dan Hadits terdapat kualifikasi dan tanggung jawab pendidik yang terdiri dari murabbī, mu'allim, muaddib, mursyid, mudarris, mutlī, dan muzakkī. Kualifikasi pendidik tersebut sebelumnya telah dicontohkan oleh Rasulullah SAW dalam mendidik umatnya sehingga Nabi Muhammad SAW merupakan contoh pendidik utama bagi umat manusia.
\end{abstract}

Kata Kunci: al-Qur`an, Hadits, Pendidik

\section{A. PENDAHULUAN}

Pendidikan merupakan suatu bentuk usaha manusia untuk mampu merespon kehidupan dengan lebih bijaksana. Terlebih aspek dunia adalah dimensi untuk manusia agar mampu membuktikan diri sebagai hamba Allah SWT yang taat. Perilaku, pikiran, dan hati dijadikan sebagai modal utama untuk mengabdi (menghamba) kepada Allah SWT sehingga kesemuanya itu harus dihiasi dan diperbaharui selalu melalui pendidikan. 
Begitu pentingnya pendidikan dalam kehidupan manusia, maka pendidikan harus ditempuh agar dapat berguna bagi kemaslahatan umat manusia. Pendidikan menjadi suatu bentuk usaha menjadikan kehidupan ini lebih bermartabat dan berperadaban. Jika tanpa pendidikan, maka tidak menutup kemungkinan manusia bisa kehilangan arah tujuan dalam hidupnya. Bahkan sejak pertama kali manusia diciptakan yaitu Nabi Adam 'alaihi al-salām telah mendapatkan pendidikan dari Allah SWT dengan memaknai hakikat perintah dan larangan Allah SWT kepadanya.

Berdasarkan sejumlah teori, adapun hakikat pendidikan dapat dilihat melalui dua sudut pandang yaitu pertama dari sudut pandang masyarakat, dari sini pendidikan dapat diartikan warisan kebudayaan dari generasi tua kepada generasi muda yang bertujuan agar hidup masyarakat tetap berlanjut, atau dengan kata lain agar suatu masyarakat mempunyai nilai-nilai budaya yang senantiasa tersalurkan dari generasi ke generasi dan senantiasa terpelihara dan tetap eksis dari zaman ke zaman.

Kedua pendidikan dapat dilihat dari sudut pandang individu, dari sini pendidikan dapat diartikan pengembangan potensi-potensi yang terpendam dan tersembunyi dalam diri setip individu, sebagai tujuan dalam memnuhi semua kemandirian dan kemampuan dalam menjalani kehidupan dan agar memenuhi semua keinginan individu tersebut. ${ }^{1}$

Pandangan tersebut lahir dari tujuan pendidikan yang mana jika tujuan pendidikan tersebut akan berubah dan akan jauh berbeda jika dihubungkan dalam agama Islam. Islam datang secara komprehensif membentuk pendidikan yang berlandaskan al-Qur'an dan al-Sunnah, di mana Islam mendidik individu menjadi manusia yang beriman, berakhlak yang mulia dan beradab yang kemudian melahirkan masyarakat yang bermartabat, teori ini didasarkan pada firman Allah SWT:

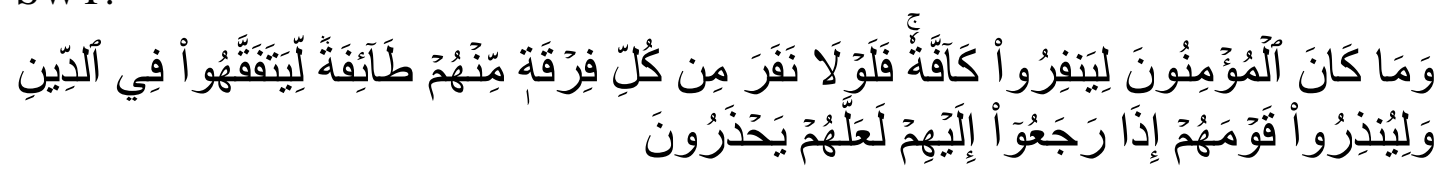

Artinya: Tidak sepatutnya bagi mukminin itu pergi semuanya (ke medan perang). Mengapa tidak pergi dari tiap-tiap golongan di antara mereka beberapa orang untuk memperdalam pengetahuan mereka tentang agama dan untuk memberi

\footnotetext{
${ }^{1}$ Hasan Langgulung, Asas-Asas Pendidikan Islam (Jakarta: Pustaka al-Husna, 1987), 3.
} 
peringatan kepada kaumnya apabila mereka telah kembali kepadanya, supaya mereka itu dapat menjaga dirinya. (Q.S. al-Taubah: 122) ${ }^{2}$

Ayat tersebut memberi penegasan terutama kepada orang-orang yang beriman dalam berjuang menegakkan dan menjunjung tinggi agama Allah SWT tidaklah hanya menggunakan jihad secara fisik namun juga tidak kalah pentingnya adalah menggunakan jihad ilmiah (akademik atau keilmuan) baik dalam aspek ilmu-ilmu agama dan juga ilmu umum. Semua ilmu pengetahuan merupakan anugerah yang berharga sehingga kaum beriman harus dapat meraihnya dengan maksimal. Sebagaimana sabda Rasulullah Muhammad SAW dalam suatu haditsnya yaitu menyatakan:

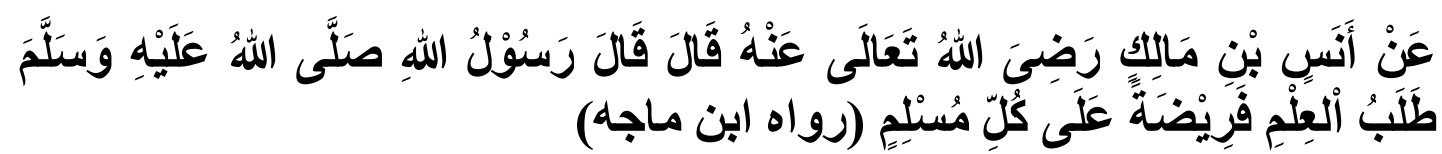

Artinya: Dari Anas bin Malik radhiyallāhu ta'ālā 'anhu telah berkata, telah bersabda Rasulullah SAW: menuntut ilmu adalah suatu kewjiban bagi setiap individu muslim. (H.R. Ibnu Majah).

Maka telah jelas begitu pentingnya menuntut ilmu atau biasa dikenal dengan menempuh suatu pendidikan dalam pandangan Islam dengan banyaknya perintah dari al-Qur`an dan Hadits mengenai tentang hal tersebut. Pendidikan dalam arti menebarkan dan menuntut ilmu menjadi suatu kewajiban bagi setiap orang Islam secara keseluruhan. Berawal dari perintah ini, maka dapat dimaknai bahwa dalam ajaran Islam (melalui ayat al-Qur'an dan teks Hadits) memberikan ajaran dan anjuran yang sangat dalam tentang pentingnya melaksanakan perintah agama (hidup beragama) dengan dilandasi pemahaman keilmuan yang utuh dan menyeluruh. Konteks pendidikan terutama dalam pendidikan Islam, tentunya memandang penting untuk mencapai suatu tujuan pendidikan, seorang pendidik menjadi tokoh utama dalam mengantarkan peserta didik untuk sukses mencapai tujuan pendidikan. Pendidik yang dikenal juga sebagai seorang guru merupakan orang yang bertanggung jawab terhadap setiap perkembangan peserta didik dalam menuntut ilmu. Begitu sentral dan pentingnya posisi seorang guru dalam dunia pendidikan, maka Islam dalam ajarannya juga sangat menghormati dan menjunjung tinggi profesi sebagai seorang pendidik yang banyak dijumpai dalam ayat-ayat al-Qur`an maupun teks-teks Hadits.

${ }^{2}$ Kementerian Agama RI dan Kementerian Haji dan Wakaf Arab Saudi, Al-Qur`an Dan Terjemahnya (Madinah: Mujamma' Khadim al-Haramain asy-Syarifain al-Malik Fahd li Thiba'at alMushhaf asy-Syarif, 1971), 301-302. 
Sebelumnya perlu diketengahkan di sini, makna dari pendidik itu secara formal, di samping di dalam penelitian ini juga dibahas dalam inti penelitian arti pendidik dalam pandangan al-Qur`an dan Hadits (menurut ajaran Islam). jika sedikit melihat dari peraturan Undang-Undang Republik Indonesia nomor 14 tahun 2005 mengenai Guru dan Dosen menyatakan yang dimaksud guru adalah seorang pendidik profesional dengan tugas utama mendidik, mengajar, membimbing, mengarahkan, melatih, menilai, dan mengevaluasi peserta didik pada pendidikan anak usia dini jalur pendidikan formal, pendidikan dasar, dan pendidikan menengah. ${ }^{3}$

Pendidik memerlukan suatu konsep ideologis religius agar dalam proses pengajaran tidak hanya terkesan sebagai transfer of knowledge namun juga menjadi proses transfer of value mengenai substansi dari suatu pendidikan yang dilihat dari banyak aspek baik secara kognitif, afektif, dan psikomotorik. Salah satu caranya adalah dengan memahami terlebih dahulu sumber ajaran Islam yaitu al-Qur`an dan Hadits dalam memandang pendidik sebagai subjek dari pendidikan itu sendiri. Pendidik memiliki suatu peranan yang sangat penting serta mempunyai wewenang lebih dalam penyelenggaraan suatu pendidikan sehingga jika pendidik tidak dilandasi pemahaman akan fungsi ideologis religiusnya yang didasarkan pada alQur`an dan Hadits dalam praktik mengajarnya maka pendidikan akan mengalami kehampaan dari nilai-nilai religius dan moralitas, yang pada akhirnya dapat berdampak secara serius pada perkembangan aspek kognitif, afektif, dan psikomotorik peserta didik.

Maka tidak heran hari demi hari sering kali terdengar banyak kasus terjadi secara negatif yang melibatkan peserta didik, jika ditelaah lebih dalam bisa sangat dimungkinkan ini merupakan akibat dari suatu sistem pendidikan yang hampa dari nilai-nilai religius dengan melibatkan pendidik yang juga tidak didasari pengetahuan akan fungsi religiusnya berdasarkan al-Qur`an dan Hadits di dalam praktik pengajarannya.

Memandang beragam alasan utama di atas, maka penting untuk dibahas dalam penelitian ini mengenai perspektif al-Qur`an dan Hadits tentang kualifikasi dan tanggung jawab pendidik dalam pembelajaran Pendidikan Agama Islam (PAI) dengan tujuan agar diperoleh suatu pemahaman yang utuh akan peran dan fungsi

\footnotetext{
${ }^{3}$ Undang-Undang Republik Indonesia Nomor 14 Tahun 2005 tentang Guru dan Dosen.
} 
pendidik berdasarkan al-Qur`an dan Hadits sehingga nantinya dapat diimplementasikan dalam proses dan praktik pengajaran.

\section{B. LANDASAN TEORI}

\section{Konsep Pembelajaran Pendidikan Agama Islam}

Pembelajaran merupakan usaha atau pun kegiatan yang mengutamakan proses interaksi antara pendidik dengan peserta didik. Namun dalam konteks pendidikan agama Islam juga mementingkan peran sentral seorang pendidik yang menjadi figur keteladanan bagi peserta didiknya. Hal ini menyebabkan dalam pendidikan agama Islam sangat menjunjung tinggi peranan seorang pendidik, guru, ulama, kiai, ustadz, dan semisalnya. Menyimak pendapat Herman H. Horne yang menyatakan pendidikan merupakan proses penyesuaian diri manusia secara timbal balik dengan alam sekitar, dengan sesame manusia, dan dengan tabiat tertinggi dari kosmos. ${ }^{4}$ Pada pengertian ini maka proses tersebut menyangkut proses seseorang menyesuaikan dirinya dengan dunia sekitarnya.

Terdapat setidaknya tiga terminologi yang mewakili Pendidikan Agama Islam (PAI) yaitu al-tarbiyyah, al-ta'līm, dan $a l$-ta'dīb. ${ }^{5}$ Kesemuanya memiliki maksud dan tujuan yang hampir sama. Hanya saja perbedaan terletak pada luas fokus atau objek pembahasannya. Istilah al-tarbiyah memiliki cakupan yang paling luas yaitu pendidikan dari perspektif secara makro termasuk di dalamnya terdapat unsur pendidikan, pengajaran, pembimbingan, pelatihan, pendampingan, dan lain sebagainya semua yang termasuk unsur edukatif.

Teori menyatakan pendidikan Islam merupakan paradigma ilmu pengetahuan atau disiplin ilmu yang membahas masalah-masalah pendidikan yang berdasarkan pada kawasan ijtihad basyari yaitu Islam (al-Qur`an, hadits, dan pemikiran). ${ }^{6}$ Pendidikan Islam sebagaimana pendapat Ahmad Marimba yang dijelaskan kembali dalam Nur Uhbiyati menyatakan pendidikan Islam adalah bimbingan jasmani, ruhani berdasarkan hukum-hukum agama Islam menuju kepada terbentuknya kepribadian utama menurut ukuran-ukuran Islam. Kepribadian utama adalah

\footnotetext{
${ }^{4}$ Khoiron Rosyadi, Pendidikan Profetik (Yogyakarta: Pustaka Pelajar, 2004), 136.

5 Abdul Halim, Filsafat Pendidikan Islam: Pendekatan Historis, Teoritis, Dan Praktis (Jakarta: Ciputat Press, 2002), 25.

${ }^{6}$ Saifullah, Hakikat Dan Tujuan Pendidikan Islam (Perspektif Muhammad Quthb, (Jurnal Pencerahan, Vol. 5, No. 2, 2007), 88-102.
} 
kepribadian muslim dengan maksud bahwa kepribadian yang memiliki nilai-nilai agama Islam. ${ }^{7}$

Hampir sama pula ketika uraian pendidikan Islam dijelaskan oleh Ali Ashraf yaitu pendidikan yang melatih sensibilitas peserta didik dengan sebaik-baiknya, sehingga perilaku mereka di dalam kehidupan, langkah-langkah dan keputusan begitu pula pendekatan mereka terhadap semua ilmu pengetahuan diatur oleh nilainilai etika Islam yang sangat dalam dirasakan. ${ }^{8}$

\section{HASIL DAN ANALISIS PENELITIAN}

\section{Hakikat Pendidik}

Misi profetis pendidikan Islam sebenarnya adalah sesuai dengan misi kenabian dan kerasulan Muhammad SAW sebagaimana yang telah tertulis dalam kitab suci al-Qur`an surat al-Anbiya’ ayat 107 yaitu:

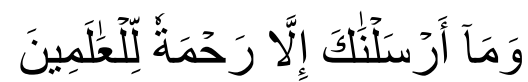

Artinya: dan tiadalah Kami mengutus kamu, melainkan untuk (menjadi) rahmat bagi semesta alam. (Q.S. al-Anbiya': 107) ${ }^{9}$

Melihat misi profetis tersebut, maka pendidikan Islam memiliki tujuan untuk menebarkan nilai-nilai positif kepada siapa pun terutama peserta didik agar tercipta kedamaian dalam kehidupan dunia yang menjadi jalan bagi tercapainya kehidupan akhirat yang bahagia. Tentu hal semacam ini tidak dapat dilepaskan dari peran seorang pendidik agar misi profetis pendidikan Islam dapat terwujud secara optimal. Jika melihat peranan Rasulullah Muhammad SAW yang juga sebagai seorang pendidik utama, misi kependidikan pertama yang dilakukan oleh Nabi Muhammad SAW adalah misi dan pendidikan tauhid yaitu menanamkan akidah atau keyakinan untuk mengesakan Allah SWT dengan cara memahami seluruh fenomena alam dan kemanusiaan sebagai suatu kesatuan yang holistik. Dalam kerangka tauhid dalam pengertian ini, kemanusiaan yaitu Sumber Daya Manusia (SDM) adalah manusia yang memiliki kualitas seimbang antara beriman, berilmu, dan beramal. Memiliki kecakapan secara lahiriyah dan batiniyah, berkualitas secara emosional dan rasional

\footnotetext{
${ }^{7}$ Nur Uhbiyati, Ilmu Pendidikan Islam (Bandung: Pustaka Setia, 1998), 5.

${ }^{8}$ Ali Ashraf, Horison Baru Pendidikan Islam (Jakarta: Pustaka Firdaus, 1996), 23.

9 Kementerian Agama RI dan Kementerian Haji dan Wakaf Arab Saudi, Al-Qur'an Dan Terjemahnya, Op.Cit., 508.
} 
atau memiliki EQ dan IQ yang sama-sama tinggi. ${ }^{10}$ Pendidikan tauhid yang diajarkan oleh Rasulullah Muhammad SAW ini ditunjukkan melalui metode keteladanan ketika pada periode dakwah di kota Mekkah. Menggunakan metode keteladanan dan berperan sebagai pendidik utama, Rasulullah SAW memiliki misi profetis utama yaitu membangun masyarakat bertauhid, meletakkan dasar-dasar fundamental bagi pembentukan nucleus masyarakat historis yang vi-able untuk menjawab tantangan zaman.

Adapun setelah hijrah ke Madinah, Nabi Muhammad SAW melaksanakan fungsi beliau sebagai pendidik utama dalam pembangunan masyarakat sosial politik keagamaan Islam Madinah. Di Madinah, Nabi SAW tidak hanya menciptakan tatanan politik, seperti diatur dalam Konstitusi Madinah (Mìtsāq al-Madīnah), tetapi juga membangun tradisi pendidikan Islam dengan fungsionalisasi masjid, misalnya, tidak hanya sebagai tempat melakukan shalat, tetapi juga untuk menyelenggarakan pendidikan dalam pengertian seluas-luasnya. ${ }^{11}$

Di sinilah, fungsi dan misi profetis Rasulullah SAW sebagai seorang pendidik utama dalam memberikan edukasi religius kepada para sahabatnya dan masyarakat di sekitarnya, tanpa memandang latar belakang mereka, baik agama, suku, ras, golongan, dan sebagainya. Berbekal mukjizat al-Qur`an yang diberikan oleh Allah SWT, memiliki kepribadian dan karakter istimewa, pribadi yang suka melakukan refleksi dan merenung tentang alam lingkungan, masyarakat sekitarnya dan Tuhan, selalu belajar di sekolah tanpa dinding (school without wall), berkepribadian terpuji dan mulia, dan suka mencari hikmah, maka bisa dipastikan Rasulullah SAW menjadi contoh sempurna sebagai pendidik utama yang berhasil membentuk suatu peradaban unggul dan mulia.

Hakikat pendidik utama pada diri Rasulullah SAW justru sebenarnya telah tercantum dalam surat al-Ahzab ayat 45-46 sebagaimana berikut ini:

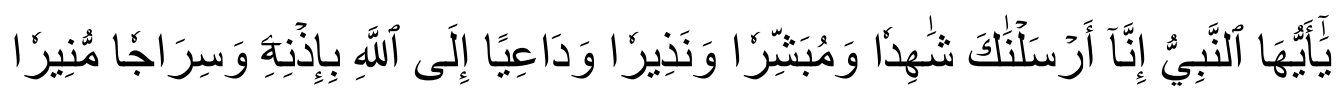

Artinya: Hai Nabi, sesungguhnya Kami mengutusmu untuk jadi saksi, dan pembawa kabar gemgira dan pemberi peringatan, dan untuk jadi penyeru kepada agama Allah dengan izin-Nya dan untuk jadi cahaya yang menerangi. (Q.S. alAhzab: 45-46) ${ }^{12}$

10 Azyumardi Azra, Pendidikan Islam: Tradisi Dan Modernisasi Di Tengah Tantangan Milenium III (Jakarta: Penerbit Kencana, 2014), 62.

${ }^{11}$ Ibid., 62.

12 Kementerian Agama RI dan Kementerian Haji dan Wakaf Arab Saudi, Al-Qur`an Dan Terjemahnya, Op.Cit., 675. 
Sebagai utusan Allah SWT untuk memberi kabar gembira dan suatu peringatan, maka di situlah hakikat sebenarnya Rasulullah SAW sebagai seorang pendidik utama. Tentunya, sebagai pemberi kabar gembira maka di dalamnya memuat suatu metode khusus agar manusia mengikuti dan berada dalam unsur kabar gembira tersebut. Itulah fungsi pendidik utama yang ada pada pribadi Rasulullah SAW berperan untuk membimbing manusia dan sekaligus menjadi guru utama. Demikian pula halnya pada peran sebagai pemberi suatu peringatan, maka fungsi pendidik utama dalam diri Rasulullah SAW juga sangat berperan penting. Hal ini tercermin pada usaha yang dilakukan Nabi SAW dalam mengarahkan para sahabatsahabatnya dan siapa pun untuk selalu menghindari perbuatan-perbuatan tercela, termasuk melalui keteladanan yang selalu beliau contohkan setiap harinya.

Pendidik dalam Islam adalah semua atau pun siapa saja yang bertanggung jawab terhadap perkembangan anak didik. Dalam Islam, orang yang paling bertanggung jawab adalah orang tua (ayah dan ibu) anak didik. Pada awalnya tugas pendidik adalah murni tugas kedua orang tua, namun pada perkembangan zaman yang telah maju seperti sekarang ini, banyak tugas orang tua sebagai pendidik yang diserahkan ke sekolah, karena lebih efisien dan lebih efektif. ${ }^{13}$

Nur Uhbiyati memberikan definisi tentang pendidik; adalah orang dewasa yang bertanggung jawab memberi bimbingan atau bantuan kepada anak didik dalam perkembangan jasmani dan rohaninya agar mencapai kedewasaannya, mampu melaksanakan tugasnya sebagai makhluk Allah, khalifah di permukaan bumi, sebagai makhluk sosial, dan sebagai individu yang sanggup berdiri sendiri. ${ }^{14}$

\section{Perspektif al-Qur`an dan Hadits tentang Kualifikasi dan Tanggung Jawab Pendidik}

Pendidik atau sebutan lainnya adalah guru, pada konteks pendidikan Islam, sebenarnya selalu merujuk atau mendasarkan pada tekstualitas suatu nash al-Qur`an dan Hadits sebagai sumber utama pendidikan Islam. Ketika konsep pendidik selalu diidentikkan dengan suatu pembelajaran di kelas, namun dalam pendidikan Islam dengan sumber utama al-Qur`an dan Hadits tidak membatasi konsep pendidik hanya pada pembelajaran di sekolah, tetapi sangat luas yaitu segala bentuk dimensi kehidupan, itulah ruang kerja dari seorang pendidik yang sebenarnya. Berikut ini

13 Ahmad Tafsir, Ilmu Pendidikan Dalam Perspektif Islam (Bandung: Remaja Rosdakarya, 1994), 74-75.

14 Nur Uhbiyati, Ilmu Pendidikan Islam, Op.Cit., 65. 
akan diklasifikasikan terkait kualifikasi dan tanggung jawab seorang pendidik berdasarkan perspektif al-Qur`an dan Hadits, yaitu:

a. Kualifikasi dan Tanggung Jawab Pendidik Sebagai Murabbī

Seorang pendidik adalah orang yang memiliki tanggung jawab yang mulia untuk membimbing dan mengarahkan peserta didik agar memiliki kepribadia yang mulia. Sebagaimana ketika Allah SWT mendidik langsung Rasulullah SAW di dalam surat al-Rahman ayat 2-4 yaitu:

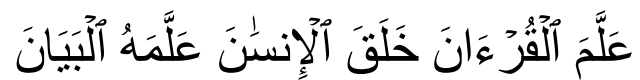

Artinya: Yang telah mengajarkan al-Qur`an. Dia menciptakan manusia. Mengajarnya pandai berbicara. (Q.S. al-Rahman: 2-4) ${ }^{15}$

Kemudian Allah SWT juga mendidik para hamba-Nya melalui diutusnya seorang Rasul dari kalangan mereka. Keberadaan seorang Rasul tersebut adalah untuk mengajarkan risalah Ilahi kepada umat manusia sebagaimana ayat berikut ini:

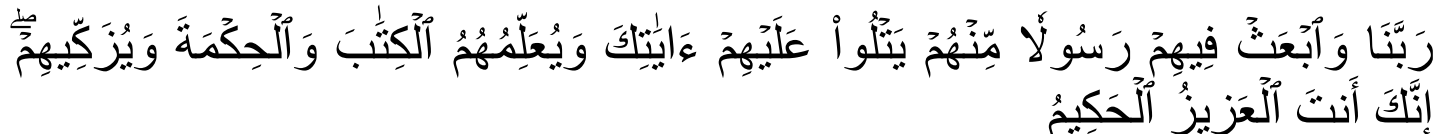

Artinya: Ya Tuhan kami, utuslah untuk mereka seorang Rasul dari kalangan mereka, yang akan membacakan kepada mereka ayat-ayat Engkau, dan mengajarkan kepada mereka al-Kitab (al-Qur`an) dan al-Hikmah (al-Sunnah) serta mensucikan mereka. Sesungguhnya Engkaulah yang Maha Kuasa lagi Maha Bijaksana. (Q.S. al-Baqarah: 129) ${ }^{16}$

Melihat beberapa ayat al-Qur`an tersebut telah dijelaskan secara tegas bahwa Allah SWT sebagai Pencipta juga melakukan pendidikan kepada para rasul-Nya. Sehinga risalah Ilahi dapat diterima oleh umat manusia yang diperoleh berkat peranan rasul Allah SWT sebagai murabbī untuk mendidik dan mengarahkan manusia kepada jalan kebenaran. Hadits Rasulullah SAW tidak terdapat kata-kata yang sama persis dengan murabbī akan tetapi akar kata yang ada hubungannya dengan murabbī banyak ditemukan di dalam sabda Rasulullah SAW. Berikut ini contoh salah satu sabda Rasulullah SAW yang berkaitan dengan konsep murabbī كتاب yaitu pada hadits nomor 50 yang diriwayatkan oleh Imam Bukhari pada bab الإيمان tentang:

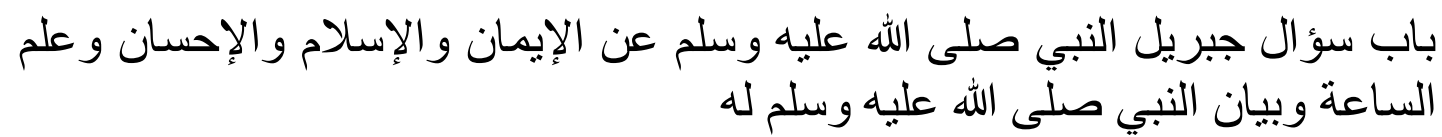

Hadits tersebut berbunyi sebagaimana berikut ini yaitu:

${ }^{15}$ Kementerian Agama RI dan Kementerian Haji dan Wakaf Arab Saudi, Al-Qur an Dan Terjemahnya, Op.Cit., 885.

${ }^{16}$ Ibid., 33. 


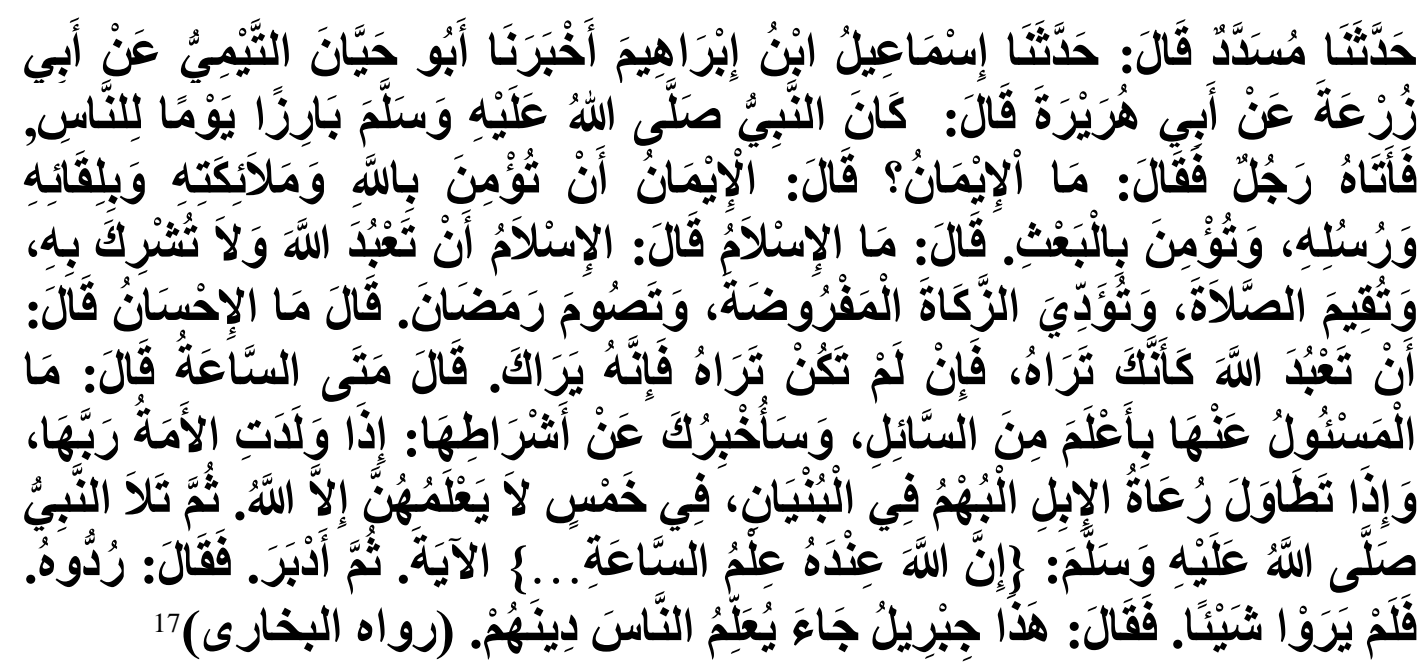

Artinya: Menceritakan kepada kami Musaddad berkata: menceritakan kepada kami Ismail ibn Ibrahim, memberitakan kepada kami Abu Hayyan al-Taymiy dari Abi Zur'ah dari Abu Hurairah telah berkata: pada suatu hari ketika Nabi SAW sedang duduk bersama sahabat, tiba-tiba datang Jibril kemudian bertanya: apakah itu iman?, Nabi SAW menjawab: iman adalah percaya kepada Allah SWT, para malaikat-Nya, dan pertemuan dengan-Nya, para rasul-Nya, dan percaya pada hari kebangkitan dari kubur. Lalu Jibril bertanya kembali, apakah itu Islam?, Nabi SAW menjawab, Islam adalah menyembah kepada Allah SWT dan tidak menyekutukanNya dengan sesuatu apapun, mendirikan shalat, menunaikan zakat yang diwajibkan, dan berpuasa di bulan Ramadhan. Lalu Jibril bertanya lagi, apakah itu ihsan?, Nabi SAW menjawab, ihsan adalah menyembah kepada Allah SWT seolah-olah engkau melihat-Nya. Jika engkau tidak melihat-Nya, ketahuilah bahwa Allah SWT melihatmu. Lalu ia bertanya lagi, kapan hari kiamat itu?, Nabi SAW menjawab, orang yang ditanya tidak lebih mengetahui daripada orang yang bertanya, tetapi saya beritahukan kepadamu beberapa syarat (tanda-tanda) akan tiba hari kiamat yaitu jika budak sahaya (perempuan) telah melahirkan majikannya, dan jika penggembala unta dan ternak lainnya telah berlomba-lomba membangun gedunggedung. Dan termasuk dalam lima macam yang tidak dapat mengetahuinya kecuali Allah SWT. Kemudian Nabi SAW membaca ayat: sesungguhnya Allah hanya pada sisi-Nya sajalah yang mengetahui hari kiamat, dan Dia pula yang menurunkan hujan dan mengetahui apa yang ada dalam rahim ibu, dan tidak seorang punyang mengetahui di manakah ia akan mati. Sesungguhnya Allah Maha Mengetahui sedalam-dalamnya (Q.S. Luqman: 34). Kemudian orang itu pergi. Lalu Nabi SAW menyuruh sahabat, antarkanlah orang itu. Maka Nabi SAW bersabda: itu adalah malaikat Jibril yang datang mengajarkan agama bagimu. (H.R. Bukhari).

Dalam konsep murabbī yang dimaksudkan adalah sebagai pendidik, maka yang dilakukan adalah berusaha untuk mencontoh sifat-sifat Tuhan, sehingga akan muncul sifat-sifat yang baik pada diri seorang pendidik. Eksistensi adanya murabbī selain mengaplikasikan sika-sikap terpuji namun berkewajiban juga mengajarkan sifa-sifat terpuji tersebut kepada peserta didik. Hal semacam ini biasanya terdapat pada pelajaran materi ilmu tauhid atau akidah mengenai sifat-sifat Tuhan.

${ }^{17}$ Abū 'Abdillāh Muhammad bin Ismā'îl bin Ibrahīm bin al-Mughīrah bin Bardizbah al-Ju'fì al-Bukharī, Șahih Al-Bukhārī, Jilid 1 Juz 1, (Beirut: Dār al-Fikr, 1994), 22. 
Namun landasan tauhid ini, seharusnya pula dapat diaplikasikan dalam mata pelajaran lainnya, sehingga integrasi keilmuan agama dan keilmuan umum dapat terjadi. Pendidik pada akhirnya dapat berperilaku sebagai murabbī dengan ciri perbuatan yang dilakukannya adalah perbuatan terpuji. Dengan berusaha mengimplementasikan sifat-sifat Tuhan maka agar dapat dicapai tujuan yaitu peserta didik memiliki wawasan keilmuan yang tinggi dan moralitas yang mulia.

Berdasarkan peranan tersebut dan hadits Rasulullah SAW, terlihat besarnya tanggung jawab seorang pendidik terhadap peserta didik, oleh karena itu pendidik yang mampu melaksanakan tugas tersebut adalah pendidik yang memiliki kompetensi matang baik secara akademis maupun profesional. Peran dan fungsi murabbī sebagai pendidik mencakup banyak hal sehingga di bawah ini merupakan beberapa tanggung jawab pendidik yang harus dilakukan sebagai murabbī yaitu:

1) Memelihara aspek jasmani dan ruhani peserta didik agar tetap terus berkembang

2) Pendidik memiliki wewenang penuh dalam mengemban amanahnya sebagai pendidik bagi peserta didik

3) Mengembangkan sifat profesionalisme pendidik agar tugasnya sebagai pendidik dapat dijalankan secara optimal

4) Bertanggung jawab mengemban amanah dari Allah SWT untuk membentuk manusia pengabdi kepada Allah SWT dan khalifah di muka bumi

5) Harus memahami aspek psikologi peserta didik agar dapat memilih materi pendidikan yang cocok untuk diberikan kepada peserta didik

6) Bertanggung jawab menumbuhkembangkan potensi peserta didik

7) Mengembangkan dan menanamkan sifat al-rububiyyat dalam dirinya, dan selanjutnya menanamkannya kepada peserta didik

8) Menguasai konsep dan penerapan manajemen kelas dan menciptakan suasana belajar yang dinamis, dialogis, dan menyenangkan

b. Kualifikasi dan Tanggung Jawab Pendidik sebagai Mu'allim

Pendidik dalam sudut pandang mu'allim memberikan pengertian bahwasanya pendidik harus memiliki daya intelektualitas yang tinggi, sebagaimana yang telah dicontohkan oleh para rasul Allah SWT dalam mendakwahkan risalah ketuhanan kepada para umatnya. Sifat fathonah (kecerdasan) merupakan modal penting bagi kesuksesan suatu dakwah. Maka oleh karena itu pendidik pun harus memiliki daya 
intelektualitas untuk mengajarkan ilmunya kepada para peserta didik. Sebagaimana firman Allah SWT berikut ini:

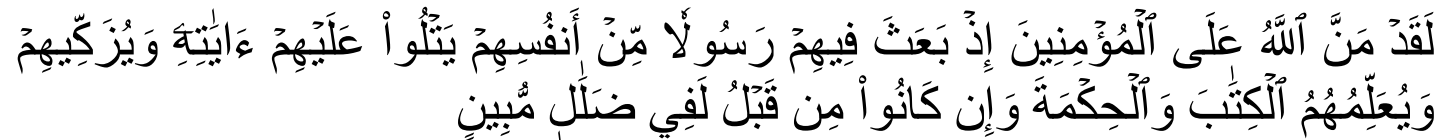

Artinya: Sungguh Allah telah memberi karunia kepada orang-orang yang beriman ketika Allah mengutus diantara mereka seorang rasul dari golongan mereka sendiri, yang membacakan kepada mereka ayat-ayat Allah, membersihkan (jiwa) mereka, dan mengajarkan kepada mereka al-Kitab dan al-Hikmah. Dan sesungguhnya sebelum (kedatangan Nabi) itu, mereka adalah benar-benar dalam kessesatan yang nyata. (Q.S. Ali Imron: 164) ${ }^{18}$

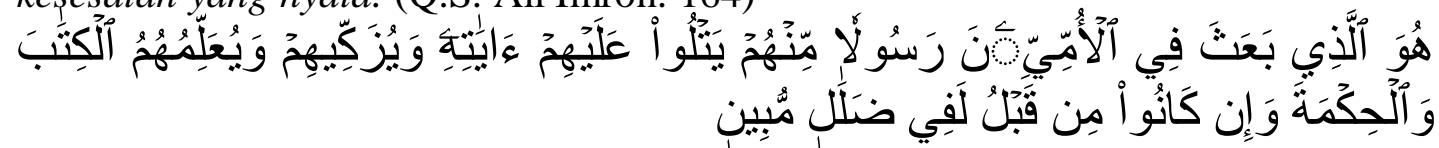

Artinya: Dialah yang mengutus kepada kaum yang buta huruf seorang Rasul di antara mereka, yang membacakan ayat-ayat-Nya kepada mereka, mensucikan mereka dan mengajarkan mereka Kitab dan Hikmah (al-Sunnah). Dan sesungguhnya mereka sebelumnya benar-benar dalam kesesatan yang nyata. (Q.S. Al-Jumu'ah: 2) ${ }^{19}$

Al-Qur`an telah memberikan tuntunan yang sangat dalam bagi pelaksanaan suatu pendidikan dari perspektif seorang pendidik. Tuntunan untuk mengajarkan ilmu dalam kerangka sebagai pengajar (mu'allim) ditekankan dengan lebih serius oleh Allah agar dapat menjadikan umat manusia sebagai khalifah di bumi dengan bekal ilmu. Suksesnya dakwah para rasul Allah justru banyak dikarenakan oleh faktor peranannya sebagai seorang mu'allim seperti yang banya dicontohkan oleh Rasulullah SAW dalam mendidik para sahabatnya dan lingkungan sekitar. Peranan Nabi Muhammad SAW sebagai seorang mu'allim membuat kota Madinah menjadi pusat peradaban dunia saat itu. Bekal keilmuan (intelektualitas) dan peran mu'allim yang dimiliki oleh Rasulullah SAW membuat banyak orang yang memusuhi dakwahnya berbalik menjadi pembela dan pendukung dakwah Islam secara totalitas dan militan.

Pentingnya aspek dan peranan mu'allim sebagaimana disabdakan oleh Rasulullah SAW pada hadits nomor 2694 dengan periwayat Imam al-Tirmidzī pada kitabnya Sunan al-Tirmidzī dalam كتاب العلم pada bab باب ما جاء في فضل الفقه على العبادة yang berbunyi:

18 Kementerian Agama RI dan Kementerian Haji dan Wakaf Arab Saudi, Al-Qur'an Dan Terjemahnya, Op.Cit., 104.

${ }^{19}$ Ibid., 932. 


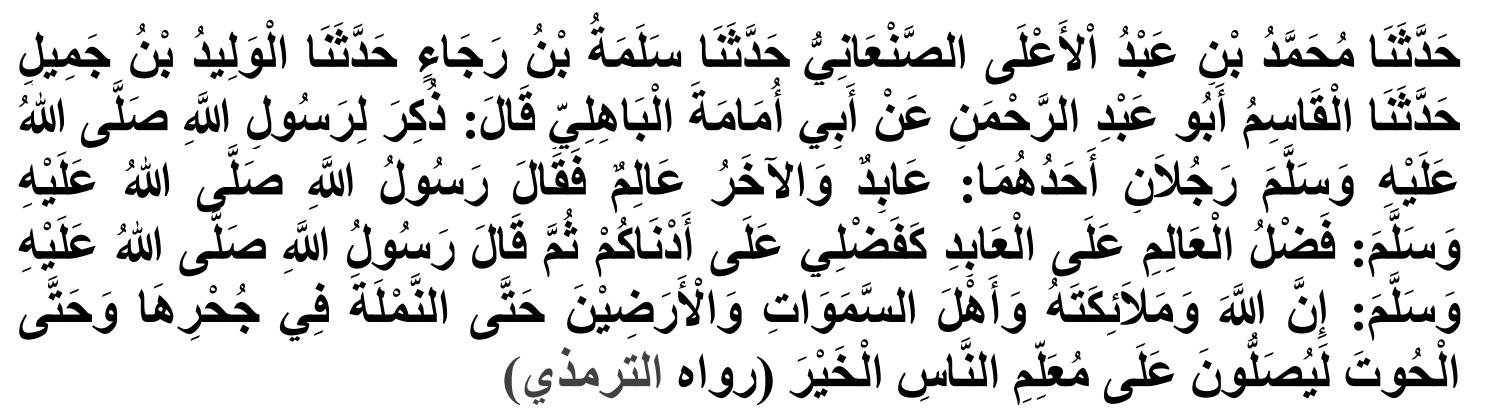

Artinya: Menceritakan kepada kami Muhammad ibn 'Abdu al-A'lā alSan 'āniy, menceritakan kepada kami Salamah ibn Rajā', menceritakan kepada kami al-Walid ibn Jamīl, menceritakan kepada kami al-Qāsim Abu 'Abdu al-Rahmān dari Abu Umamah al-Bāhilī berkata, disebutkan bagi Rasulullah SAW terdapat dua orang laki-laki, satu orang ahli ibadah, dan satu lagi ahli ilmu. Maka berkata Rasulullah SAW, keutamaan seorang ahli ilmu atas ahli ibadah seperti keutamaan antara saya dengan yang paling rendah di antara kamu. Kemudian berkata Rasulullah SAW, sesungguhnya Allah SWT, para malaikat-Nya, penduduk langit dan bumi hingga semut yang berada pada batu dan ikan, mereka bershalawat kepada seorang pendidik yang mengajarkan kebaikan. (H.R. al-Tirmidzīi) ${ }^{20}$

Kemudian didukung oleh sabda Rasulullah SAW yang lain terdapat pada hadits yang diriwayatkan oleh Imam Muslim nomor 6796 dalam kitab Ṣahīh Muslim

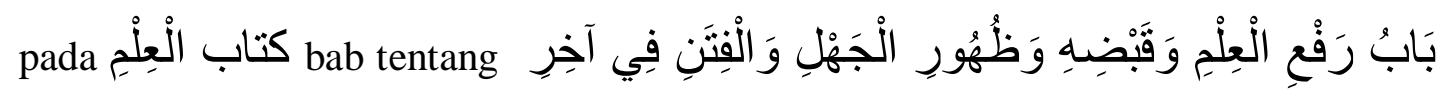
بَابُ في قبض dan terdapat dalam kitab Mukhtașar Șah̄ih Muslim pada bab الزَّمَانِ yang berbunyi sebagaimana berikut:

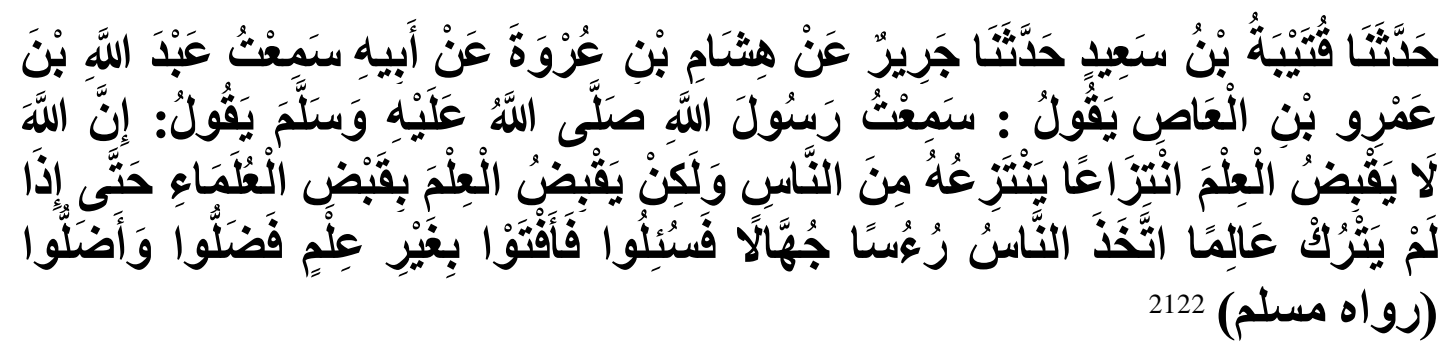

Artinya: Menceritakan kepadaku Qutaibah ibn Sa'ìd, menceritakan kepada kami Jarīr, dari Hisyām ibn 'Urwah, dari ayahnya, aku mendengar 'Abdullāh ibn 'Amr ibn al- 'Ash berkata, aku mendengar Rasulullah SAW bersabda: sesungguhnya Allah SWT tidak mengambil ilmu dengan cara mencabutnya begitu saja dari manusia, akan tetapi Allah SWT akan mengambil ilmu dengan cara mencabut (nyawa) para ulama, sehingga ketika Allah SWT tidak meninggalkan seorang ulama pun, manusia akan mengangkat pemimpin-pemimpin yang bodoh yang apabila

${ }^{20}$ Abū 'Īsā Muhammad bin 'Īsā bin Saurah al- Tirmidzī, Sunan Al-Tirmidzī, Juz 4, (Beirut: Dār al-Fikr, 2001), 313-314.

${ }^{21}$ al-Imām Ab̄̄ al-Husain Muslim bin al-Hajjāj bin Muslim al-Qusyairiyyi Al-Naisābūriyyi, Șah̄̄h Muslim (Riyadh: Dār al-Salām li al-Nasyri wa al-Tauz̄̄’i, 2000), 1164.

${ }^{22}$ al-Imām Abī al-Husain Muslim bin al-Hajjāj bin Muslim al-Qusyairiyyi Al-Naisābūriyyi, Sahīh Muslim (Beirut: Dār al-Kutub al-'Ilmiyyah, 2011), 1030. 
ditanya mereka akan memberikan fatwa tanpa didasarkan ilmu lalu mereka pun sesat serta menyesatkan. (H.R. Muslim) ${ }^{23}$

Berdasarkan beberapa hadits tersebut mengenai keutamaan ilmu yang termanifestasikan dalam peran seorang mu'allim atau orang berilmu yang memiliki kewajiban untuk mengajarkan ilmunya kepada orang lain. Di lain sisi, Allah SWT jika berkehendak mencabut suatu ilmu adalah dengan cara mencabut para mu'allim dalam yang dimaksud adalah mencabut nyawa para alim ulama. Melihat isi dari beberapa matan hadits di atas, maka diperoleh suatu konstruksi konseptual mengenai tanggung jawab seorang pendidik sebagai mu'allim yaitu di antaranya:

1) Mu'allim memiliki kedudukan utama di antara manusia, keutamaan tersebut seperti sebagai pewaris para Nabi, kemudian Allah dan para malaikat-Nya bersalawat kepada pendidik ( $m$ '́allim), dan medapatkan pahala yang terus mengalir selama ilmu yang diajarkan oleh mu'allim diamalkan oleh umat manusia

2) Bertugas mencerahkan kehidupan umat dari kebodohan

3) Mengajarkan dan mengamalkan ilmu kepada umat

4) Meluruskan pemimpin apabila salah, dan memberikan masukan bagi pengelolaan pemerintahan

5) Memiliki sifat ikhlas dalam mengajarkan ilmunya, tidak pemarah, tidak melakukan kekerasan fisik dalam mendidik, dan menunaikan amanahnya secara sempurna.

c. Kualifikasi dan Tanggung Jawab Pendidik sebagai Muaddib

Pendidik sebagai muaddib merupakan seseorang yang bertugas untuk menciptakan suasana belajar yang dapat menggerakkan peserta didik untuk berperilaku atau beradab sesuai dengan norma-norma, tata susila, dan sopan santun yang berlaku dalam masyarakat. Hal ini didasarkan pada istilah adab yang mengandung unsur identik dengan etiket atau tata cara yang baik dalam melakukan suatu pekerjaan, baik ibadah maupun muamalah. Karenanya para ulama menggariskan adab-adab tertentu dalam melakukan suatu kegiatan sesuai dengan tuntunan al-Qur`an dan Hadits. Contoh adab yang sempurna, telah dberikan teladan oleh Rasulullah SAW sebagaimana yang difirmankan Allah sebagai berikut:

${ }^{23}$ al-Hāfidz Zākiyuddin 'Abdi al-'Adhīm bin 'Abdi al-Qawiy Al-Mundziriy, Mukhtașar Șah̄̄h Muslim (Kairo: Dār al-Ghād al-Jadīd, 2007), 525. 


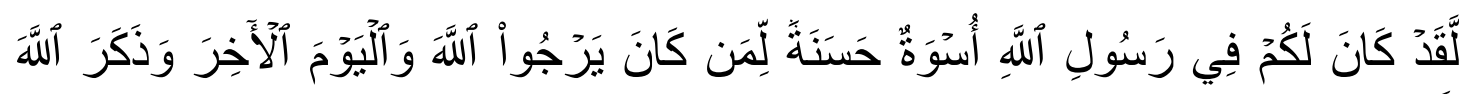

Artinya: Sesungguhnya telah ada pada (diri) Rasulullah itu suri teladan yang baik bagimu (yaitu) bagi orang yang mengharap (rahmat) Allah dan (kedatangan) hari kiamat dan dia banyak menyebut Allah. (Q.S. al-Ahzab: 21$)^{24}$

Firman Allah SWT tersebut memberikan penjelasan mengenai pribadi Rasulullah SAW yang mulia memiliki banyak teladan bagi umat manusia yang seharusnya dapat diamalkan oleh umatnya. Pendidikan berbasis keteladanan merupakan model pembelajaran yang juga dilakukan oleh pendidik yang disebut sebagai muaddib. Mengutamakan keadaban merupakan suatu realitas yang membutuhkan teladan agar dapat dicontoh, sehingga muaddib haruslah menjadi pendidik yang dapat ditiru perilakunya oleh peserta didik.

Di bawah ini adalah sabda Rasulullah Muhammad SAW mengenai ada kaitannya dengan konsep muaddib yang diriwayatkan oleh Imam Bukhari dalam

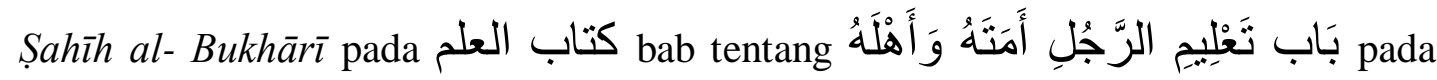
hadits nomor 97 sebagaimana berikut:

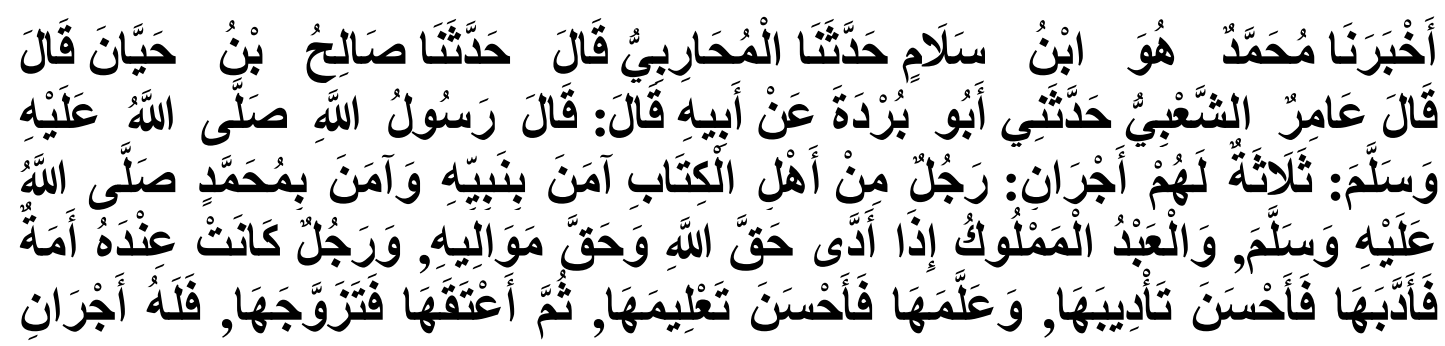

(رواه البخاري)

Artinya: Memberitahukan kepada kami, Muhammad, ia adalah ibnu Salām, menceritakan kepada kami al-Muhāribiy, ia berkata, menceritakan kepada kami Șālih ibn Hayyān, ia berkata, telah berkata 'Āmir al-Sya'biy, menceritakan kepadaku Abu Burdah dari ayahnya berkata, telah bersabda Rasulullah SAW: tiga (golongan) mendapat dua pahala yaitu seorang ahli kitab yang beriman kepada Nabinya kemudian beriman kepada Nabi Muhammad SAW, hamba sahaya apabila menunaikan hak Allah SWT dan hak tuannya (dan dalam suatu riwayat: hamba sahaya yang beribadah kepada Tuhannya dengan baik dan menunaikan kewajibannya terhadap tuannya yang berupa hak, kesetiaan, dan ketaatan, dan seorang laki-laki yang mempunyai budak wanita yang dididiknya secara baik serta diajarnya secara baik (dan dalam satu riwayat: lalu dipenuhinya kebutuhankebutuhannya dan diperlakukannya dengan baik, kemudian dimerdekakannya (kemudian menentukan mas kawinnya, lalu dikawininya, maka ia mendapat dua pahala. (H.R. Bukhari) ${ }^{25}$

24 Kementerian Agama RI dan Kementerian Haji dan Wakaf Arab Saudi, Al-Qur`an Dan Terjemahnya, Op.Cit., 670.

${ }^{25}$ Abū 'Abdillāh Muhammad bin Ismā'̄il bin Ibrahīm bin al-Mughīrah bin Bardizbah al-Ju'fì Al-Bukharī, Șahīh Al-Bukhārī, Jilid 1 Juz 1, (Beirut: Dār al-Fikr, 1994), 38. 
Hadits ini menjelaskan siapa pun yang memiliki seorang budak wanita lalu mendidiknya sehingga budak tersebut memiliki akhlak dan adab yang baik, dan memerdekakannya serta menikahinya maka baginya dua pahala. Dalam hal ini konsep muaddib sebagai pendidik lebih ditekankan kepada orang yang mendidik seseorang agar memiliki adab yang baik dan berperilaku sopan. Maka dapat diambil kesimpulan berdasarkan ayat al-Qur`an dan Hadits di atas tentang tanggung jawab seorang muaddib sebagai berikut:

1) Bertanggung jawab terhadap bimbingan dan pendidikan peserta didik agar berperilaku, berbudi pekerti, dan beradab serta sopan santun sesuai dengan ketentuan umum yang berlaku di masyarakat

2) Seorang muaddib wajib mencontoh Rasulullah Muhammad SAW dalam pendidikan konsep ta'dib karena al-Qur`an dan Hadits adalah sumber utama bagi muaddib dan akhlak Rasulullah SAW adalah al-Qur`an.

3) Muaddib harus menjadi contoh dan teladan bagi peserta didiknya

4) Seorang muaddib berkewajiban untuk mengamalkan adab dan tingkah laku yang terpuji terlebih dahulu sebelum mengajarkan kepada peserta didik.

d. Kualifikasi dan Tanggung Jawab Pendidik sebagai Mudarris

Mudarris merupakan orang yang memiliki kepekaan intelektual dan informasi serta memperbaharui pengetahuan dan keahliannya secara berkelanjutan serta berusaha mencerdaskan peserta didiknya, melawan kebodohan, melatih keterampilan sesuai dengan bakat, minat, dan kemampuannya. Dengan kata lain mudarris dimaknai sebagai orang yang mengajarkan ilmu kepada orang lain dengan metode-metode tertentu dalam upaya membangkitkan usaha peserta didik agar sadar dalam meningkatkan potensinya. Di dalam al-Qur`an disebutkan adanya usaha yang dilakukan seorang mudarris yaitu untuk selalu belajar dan mempelajari sesuatu sebagaimana berikut:

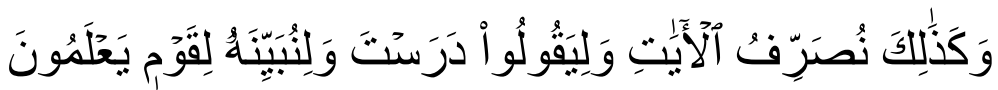

Artinya: Demikianlah Kami mengulang-ulangi ayat-ayat Kami supaya (orangorang yang beriman mendapat petunjuk) dan supaya orang-orang musyrik mengatakan: "Kamu telah mempelajari ayat-ayat itu (dari Ahli Kitab)", dan supaya 
Kami menjelaskan Al Quran itu kepada orang-orang yang mengetahui. (Q.S. alAn'am: 105$)^{26}$

Kemudian sebagai mudarris, Rasulullah SAW telah memberikan banyak contoh dalam haditsnya yang diriwayatkan Imam Abu Dawud dalam kitabnya Sunan $A b \bar{\imath} D \bar{a} w u d$ di antaranya yaitu:

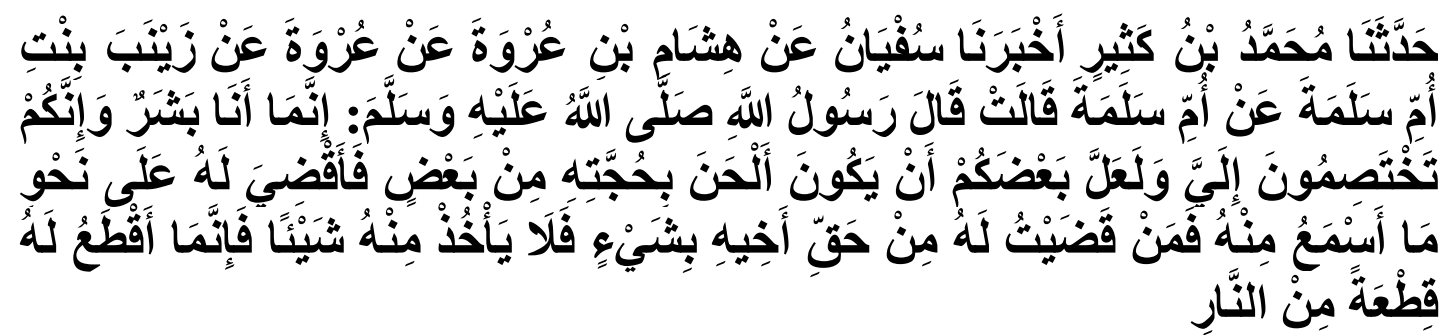

Artinya: Telah menceritakan kepada kami Muhammad bin Katsīr telah mengabarkan kepada kami Sufyan dari Hisyam bin 'Urwah dari 'Urwah dari Zainab binti Ummu Salamah ia berkata, Rasulullah SAW bersabda: Sesungguhnya aku hanyalah seorang manusia, dan kalian mengadukan permasalahannya kepadaku. Bisa jadi sebagian kalian lebih pandai dalam berdalih dari sebagian yang lain, sehingga aku memberikan keputusan untuknya sesuai dengan apa yang aku dengar darinya. Maka barangsiapa yang aku berikan suatu keputusan baginya dengan mengambil hak dari saudaranya maka janganlah ia mengambil sedikitpun darinya, karena sesungguhnya aku potongkan (api) baginya dari potongan (api) Neraka. (H.R. Abu Dawud nomor 3583).

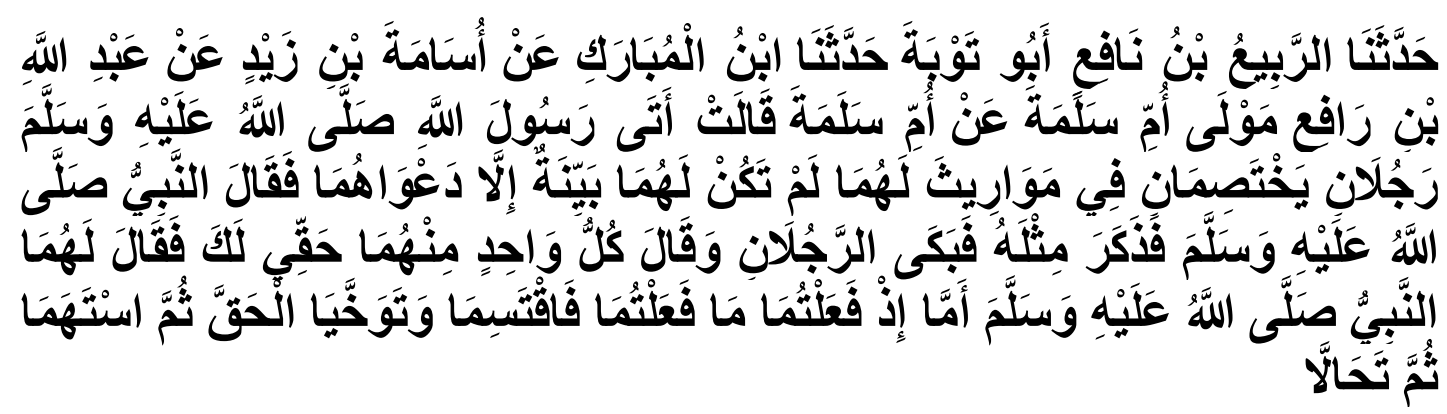

Artinya: Telah menceritakan kepada kami al-Rabī' bin Näfi' Abū Taubah telah menceritakan kepada kami Ibnu al-Mubārak dari Usāmah bin Zaid dari 'Abdillāh bin Rāfi' mantan budak Ummu Salamah, dari Ummu Salamah ia berkata: dua orang laki-laki berselisih mengenai warisan mereka berdua, sementara mereka tidak memiliki bukti kecuali pengakuan mereka saja. Lalu Nabi shallallahu 'alaihi wasallam bersabda...lalu ia menyebutkan sebagaimana hadits tersebut. Kedua laki-laki tersebut kemudian menangis, lalu setiap dari mereka berkata, hakku untukmu. Kemudian Nabi SAW berkata kepada mereka berdua: Adapun apabila kalian berdua melakukan apa yang telah kalian lakukan, maka bagilah dan berusahalah untuk bersikap benar (adil). Kemudian mereka mengundi mana bagian mereka, dan mereka saling menghalalkan untuk yang lainnya. (H.R., Abu Dawud nomor 3584),

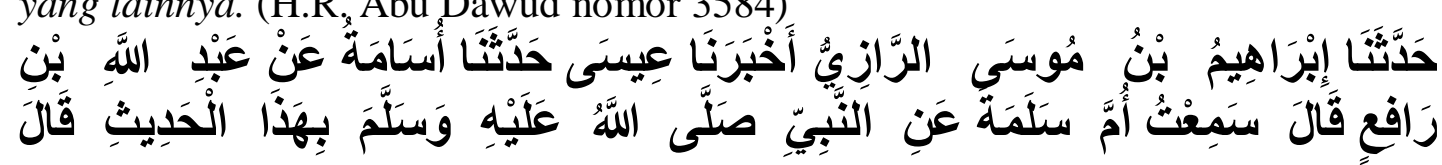

${ }^{26}$ Kementerian Agama RI dan Kementerian Haji dan Wakaf Arab Saudi, Al-Qur`an Dan Terjemahnya, Op.Cit., 205. 


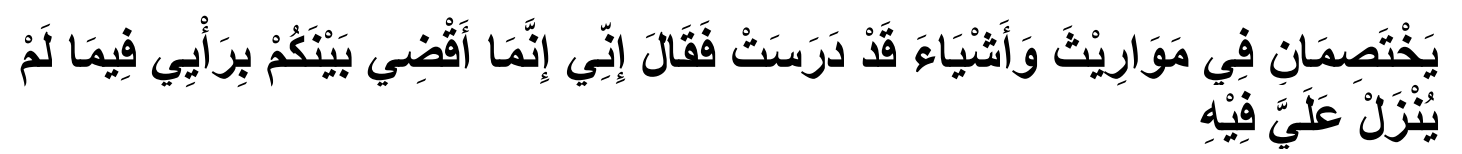

Artinya: Telah menceritakan kepada kami Ibrāhīm bin Mūsā al-Rāziyyu, telah mengabarkan kepada kami Isā, telah menceritakan kepada kami Usāmah dari 'Abdillāh bin Rāfi' berkata: aku telah mendengar Ummu Salamah dari Nabi Muhammad SAW, terhadap hadits ini keduanya berpegang teguh terhadap warisan dan sesuatu yang telah dipelajari, maka Rasulullah SAW bersabda, sesungguhnya aku memutuskan di antara kamu menurut pendapatku terhadap apa yang tidak diturunkan atasku padanya. (H.R. Abu Dawud nomor 3585) ${ }^{27}$

Berdasarkan dalil al-Qur`an dan Hadits di atas maka diperoleh tugas dan tanggung jawab mudarris adalah sebagai berikut:

1) Harus memiliki profesionalitas tinggi dalam mengembangkan potensi peserta didiknya

2) Mudarris mampu menciptakan suasana belajar yang kondusif dan harmonis

3) Menciptakan kerjasama di antara peserta didik untuk memperdalam ilmu pengetahuan

4) Mengelola dan memilih materi ajar dan mengajarkannya dengan baik kepada peserta didik

5) Mudarris harus mampu menelaah al-Qur`an karena di dalamnya banyak mengandung nilai-nilai pendidikan.

e. Kualifikasi dan Tanggung Jawab Pendidik sebagai Mursyid

Istilah mursyid dipergunakan sebagai bentuk sebutan bagi seorang pendidik dalam pendidikan Islam yang memiliki tugas membimbing peserta didik agar mampu menggunakan akal pikiran secara tepat sehingga mencapai kesadaran tentang hakikat sesuatu dan mencapai kedewasaan berpikir. Dalam ayat al-Qur`an terdapat istilah mursyidan dalam surat al-Kahfi ayat 17 yaitu:

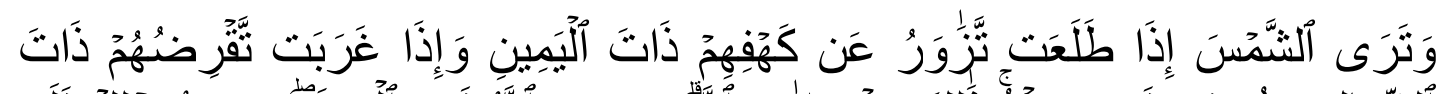

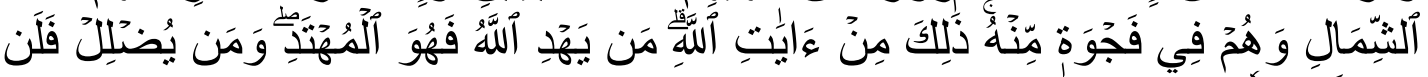

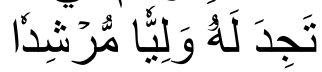

Artinya: Dan kamu akan melihat matahari ketika terbit, condong dari gua mereka ke sebelah kanan, dan bila matahari terbenam menjauhi mereka ke sebelah kiri sedang mereka berada dalam tempat yang luas dalam gua itu. Itu adalah sebagian dari tanda-tanda (kebesaran) Allah. Barangsiapa yang diberi petunjuk

${ }^{27}$ Abū Dāwud Sulaimān bin al-Asy'ats al-Sijistānī al-Azdī, Sunan Abī Dāwud, Jilid 2 Juz 3, (Beirut: Dār al-Fikr, n.d.), 301-302. 
oleh Allah, maka dialah yang mendapat petunjuk; dan barangsiapa yang disesatkan-Nya, maka kamu tidak akan mendapatkan seorang pemimpin pun yang dapat memberi petunjuk kepadanya. (Q.S. al-Kahfi: 17) ${ }^{28}$

Seorang mursyid agar mampu dan sukses memberikan pengajaran kepada peserta didik, haruslah memiliki sifat yang lemah lembut, penyayang, dan pemaaf sebagai seorang pendidik. Dengan hati yang tulus untuk mengajar maka diharapkan peserta didik dapat mencontohnya dan menanamkan ke dalam dirinya, sebagaimana firman Allah SWT:

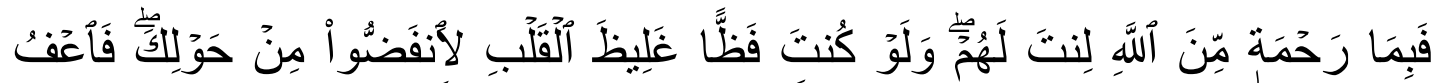

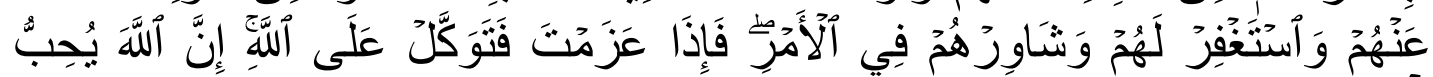
أَلْمُنَوَكِلِينَ

Artinya: Maka disebabkan rahmat dari Allah-lah kamu berlaku lemah lembut terhadap mereka. Sekiranya kamu bersikap keras lagi berhati kasar, tentulah mereka menjauhkan diri dari sekelilingmu. Karena itu maafkanlah mereka, mohonkanlah ampun bagi mereka, dan bermusyawaratlah dengan mereka dalam urusan itu. Kemudian apabila kamu telah membulatkan tekad, maka bertawakkallah kepada Allah. Sesungguhnya Allah menyukai orang-orang yang bertawakkal kepada-Nya. (Q.S. Ali Imron: 159) ${ }^{29}$

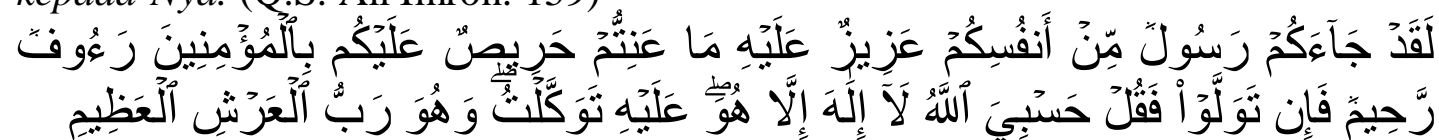

Artinya: Sungguh telah datang kepadamu seorang Rasul dari kaummu sendiri, berat terasa olehnya penderitaanmu, sangat menginginkan (keimanan dan keselamatan) bagimu, amat belas kasihan lagi penyayang terhadap orang-orang mukmin. Jika mereka berpaling (dari keimanan), maka katakanlah: Cukuplah Allah bagiku; tidak ada Tuhan selain Dia. Hanya kepada-Nya aku bertawakkal dan Dia adalah Tuhan yang memiliki 'Arsy yang Agung. (Q.S. al-Taubah: 128-129) ${ }^{30}$

Maka berdasar ayat al-Qur`an dan Hadits di atas seorang mursyid memiliki tanggung jawab yaitu:

1) Harus memiliki kejernihan berpikir dan kedewasaan berpikir

2) Memelihara dirinya dari perbuatan buruk dan senantiasa menghiasi diri dengan perbuatan terpuji

3) Membimbing peserta didik agar memiliki kejernihan berpikir, kedewasaan berpikir, dan kesadaran dalam beramal.

f. Kualifikasi dan Tanggung Jawab Pendidik sebagai Mutlī

${ }^{28}$ Kementerian Agama RI dan Kementerian Haji dan Wakaf Arab Saudi, Al-Qur`an Dan Terjemahnya, Op.Cit., 445.

${ }^{29}$ Ibid., 103.

${ }^{30}$ Ibid., 303. 
Pendidikan dalam konteks sebagai mutlī adalah orang yang membacakan sesuatu kepada orang lain. Jika dikaitkan dalam pendidikan Islam maka mutlī merupakan seseorang yang bertanggung jawab terhadap perkembangan peserta didik, terutama yang berhubungan dengan kemampuan membaca baik secara lisan maupun tertulis serta mampu memahaminya dan menerjemahkannya dalam kehidupan. Firman Allah SWT memberikan secara tersirat hakikat mutli yaitu selain unsur membaca, maka seorang mutlī lebih ditekankan untuk memiliki motivasi memperbaharui pengetahuan dengan bertanya. Selain membaca juga diperbanyak dengan bertanya kepada ahlinya:

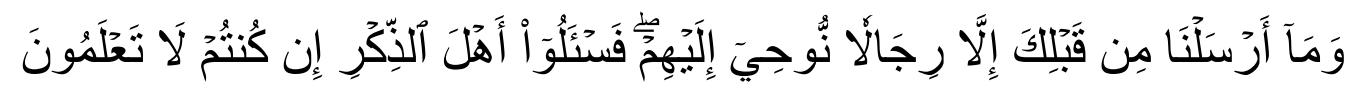

Artinya: Dan Kami tidak mengutus sebelum kamu, kecuali orang-orang lelaki yang Kami beri wahyu kepada mereka; maka bertanyalah kepada orang yang mempunyai pengetahuan jika kamu tidak mengetahui

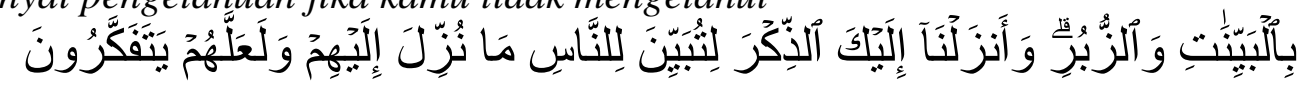

Artinya: Keterangan-keterangan (mukjizat) dan kitab-kitab. Dan Kami turunkan kepadamu al-Qur`an, agar kamu menerangkan pada umat manusia apa yang telah diturunkan kepada mereka dan supaya mereka memikirkan. (Q.S. alNahl: 43-44) $)^{31}$

Ayat tersebut memberikan makna tersirat tentang tanggung jawab yang harus dilakukan oleh seorang mutlī yaitu:

1) Bertanggung jawab pada perkembangan kemampuan membaca peserta didik secara komprehensif

2) Mengamalkan hasil bacaannya dan apa yang disampaikannya agar peserta didik juga dapat mencontohnya

3) Harus senantiasa membaca al-Qur`an agar dapat menerangi hatinya, dan sumber pengajaran yang sempurna

4) Senantiasa memotivasi peserta didik untuk gemar membaca ayat qauliyah dan kauniyah.

g. Kualifikasi dan Tanggung Jawab Pendidik sebagai Muzakkī

Muzakkī adalah orang yang membersihkan dan mensucikan sesuatu agar menjadi bersih dan suci terhindar dari kotoran. Dalam konteks pendidikan Islam muzakkī adalah pendidik yang bertanggung jawab memelihara, membimbing, dan mengembangkan fitrah peserta didik agar selalu berada dalam keadaan suci untuk

\footnotetext{
${ }^{31}$ Ibid., 408.
} 
taat kepada Allah SWT dan terhindar dari perbuatan tercela. Sebagaimana dalam firman Allah SWT peran dan tanggung jawab muzakkī adalah untuk mensucikan, yang berbunyi:

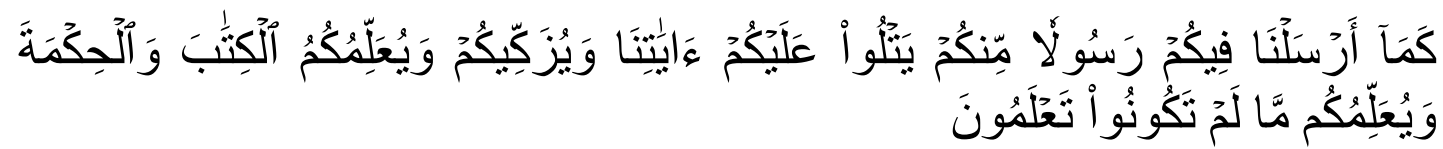

Artinya: Sebagaimana (Kami telah menyempurnakan nikmat Kami kepadamu) Kami telah mengutus kepadamu Rasul diantara kamu yang membacakan ayat-ayat Kami kepada kamu dan mensucikan kamu dan mengajarkan kepadamu al-Kitab dan al-Hikmah, serta mengajarkan kepada kamu apa yang belum kamu ketahui. (Q.S. al-Baqarah: 151$)^{32}$

Bahkan Rasulullah SAW sendiri pun adalah seorang muzakkī dalam peristiwa merubah nama Zainab yang semula bernama Barrah menjadi Zainab dengan tujuan untuk mensucikan dan membersihkan diri, hadits tersebut diriwayatkan oleh Imam كتاب sebagaimana di bawah ini:

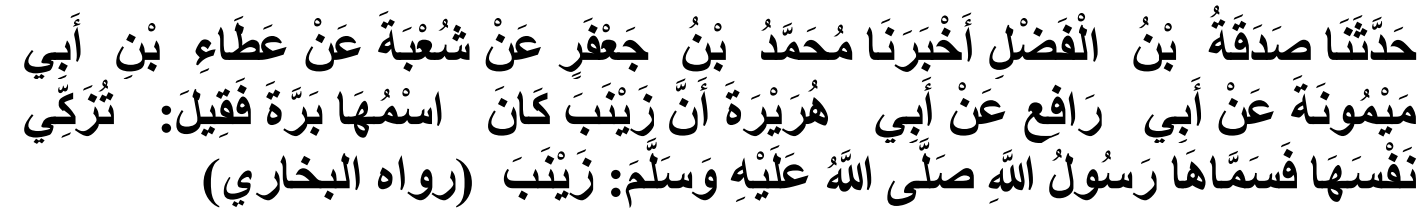

Artinya: Menceritakan kepada kami Șadaqah bin al-Fadl, telah memberitahukan kepada kami Muhammad bin Ja'far dari Syu'bah dari 'Athā' bin Abī Maimūnah dari Abī Rāfi' dari Abī Hurairah, bahwasanya pada awalnya Zainab namanya adalah Barrah, maka dikatakan untuk mensucikan dirinya, lalu Rasulullah SAW mengganti namanya dengan Zainab (H.R. Bukhari) ${ }^{33}$

Adapun tugas dan tanggung jawab pendidik dalam konteks muzakki terdapat beberapa hal yaitu:

1) Bertanggung jawab mensucikan pribadi peserta didik baik jiwa dan raganya

2) Selalu menghiasi dirinya dengan sifat-sifat terpuji sehingga terjaga kesucian jiwanya

3) Berusaha selalu menjaga kesucian jiwa peserta didik dari lingkungan internal dan eksternal di sekitarnya yang mampu memberi pengaruh negative bagi perkembangannya.

32 Ibid., 38 .

${ }^{33}$ Abū 'Abdillāh Muhammad bin Ismā'̄il bin Ibrahīm bin al-Mughīrah bin Bardizbah al-Ju'fì Al-Bukharī, Șahīh Al-Bukhārī, Jilid 4 Juz 7, (Beirut: Dār al-Fikr, 1994), 152. 


\section{KESIMPULAN DAN REKOMENDASI}

1. Kesimpulan

Rasulullah Muhammad SAW merupakan teladan bagi umat manusia secara komprehensif. Dalam konteks pendidikan maka Nabi SAW berperan sebagai pendidik yang utama bagi peradaban dunia. Jiwa pendidik yang terdapat dalam diri Rasulullah Muhammad SAW membuktikan kemampuannya untuk mengubah kondisi zaman dalam kebodohan menjadi peradaban yang mulia dan unggul. Maka unsur pendidik dalam perspektif al-Qur`an dan Hadits termanifestasikan dalam diri Rasulullah SAW sebagai pendidik utama yang dikualifikasikan dalam sebutan yaitu murabbī, mu'allim, muaddib, mursyid, mudarris, mutlī, dan muzakkī. Kesemuanya memiliki peran, tugas, dan tanggung jawabnya yang berbeda sesuai dengan kontekstualisasi dalam proses pendidikan yang dijalankannya.

2. Rekomendasi

Kualifikasi pendidik sebagai murabbī, mu'allim, muaddib, mursyid, mudarris, mutlī, dan muzakkī yang telah ada pada pribadi Rasulullah SAW selayaknya dapat diamalkan dan diaplikasikan oleh guru Pendidikan Agama Islam (PAI) dan guru yang lainnya agar sistem pendidikan di negeri ini mampu mencetak manusiamanusia yang berperadaban mulia.

\section{REFERENSI}

Al-Bukharī, Abū 'Abdillāh Muhammad bin Ismā'îl bin Ibrahīm bin al-Mughīrah bin Bardizbah al-Ju’fì. Șahih Al-Bukhārī, Jilid 4 Juz 7. Beirut: Dār al-Fikr, 1994.

Al-Mundziriy, al-Hāfidz Zākiyuddin 'Abdi al-'Adhīm bin 'Abdi al-Qawiy. Mukhtaṣar Șahīh Muslim. Kairo: Dār al-Ghād al-Jadīd, 2007.

Al-Naisābūriyyi, al-Imām Ab̄̄ al-Husain Muslim bin al-Hajjāj bin Muslim alQusyairiyyi. Șah̄̄h Muslim. Riyadh: Dār al-Salām li al-Nasyri wa al-Tauz̄̄’i, 2000.

—. Șahīh Muslim. Beirut: Dār al-Kutub al-'Ilmiyyah, 2011.

Ashraf, Ali. Horison Baru Pendidikan Islam. Jakarta: Pustaka Firdaus, 1996.

Azra, Azyumardi. Pendidikan Islam: Tradisi Dan Modernisasi Di Tengah Tantangan Milenium III. Jakarta: Penerbit Kencana, 2014.

Halim, Abdul. Filsafat Pendidikan Islam: Pendekatan Historis, Teoritis, Dan Praktis. Jakarta: Ciputat Press, 2002.

Langgulung, Hasan. Asas-Asas Pendidikan Islam. Jakarta: Pustaka al-Husna, 1987. 
RI, Kementerian Agama, and Kementerian Haji dan Wakaf Arab Saudi. Al-Qur`an Dan Terjemahnya. Madinah: Mujamma' Khadim al-Haramain asy-Syarifain al-Malik Fahd li Thiba'at al-Mushhaf asy-Syarif, 1971.

Rosyadi, Khoiron. Pendidikan Profetik. Yogyakarta: Pustaka Pelajar, 2004.

Saifullah. "Hakikat Dan Tujuan Pendidikan Islam (Perspektif Muhammad Quthb)." Jurnal Pencerahan 5, no. 2 (2007): 88-102.

Sulaimān bin al-Asy'ats al-Sijistānī al-Azd̄̄, Abū Dāwud. Sunan Abī Dāwud Jilid 2 Juz 3. Beirut: Dār al-Fikr, n.d.

Tafsir, Ahmad. Ilmu Pendidikan Dalam Perspektif Islam. Bandung: Remaja Rosdakarya, 1994.

Tirmidzī, Abū 'Īsā Muhammad bin 'Īsā bin Saurah al-. Sunan Al-Tirmidzī Juz 4. Beirut: Dār al-Fikr, 2001.

Uhbiyati, Nur. Ilmu Pendidikan Islam. Bandung: Pustaka Setia, 1998.

Undang-Undang Republik Indonesia Nomor 14 Tahun 2005 Tentang Guru Dan Dosen, n.d. 